\title{
PENGUATAN MASYARAKAT MADANI MELALUI DAKWAH KEWARGAAN
}

\author{
Muhammad Sulthon \\ IAIN Walisongo Semarang \\ Email:msuthon@yahoo.com
}

\begin{abstract}
By the end of the caliphate system, the Islamic world face many questions, among others, the question of the relationship of Mustims as citizens of the country. At the time of the new order, the majority of Muslims as citizens of the nation-state in Indonesia do not have bargaining power siginifikan in balancing the country's dominance. This relationship is not conducive to the process of democratization. To overome it appears some ibtiar, among citizenry missionary movement to create a civil society. Missionary citizenship can be done by mengintermalisasitean Islamic values relevant to the citirens of the community.
\end{abstract}

Alinin

وبحلول نهاية نظام الخلافة، العالم الإسلامي يواجه العديد من الأسئلة، من بين أمور أخرى.

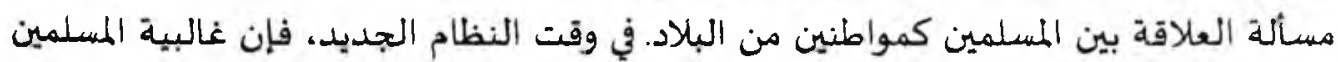
كمواطنين في الدولة القومية في اندونيسيا لم يكن لديك القدرة على المساومة كبيرة في موازنة المبنه

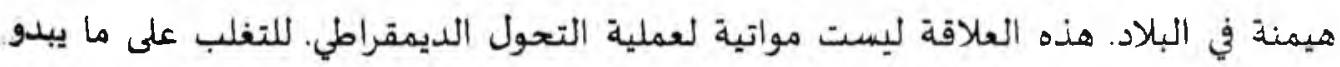

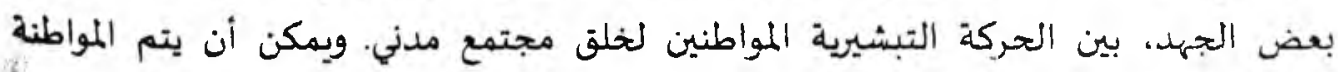

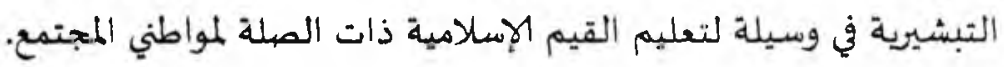

Regwords: masyarakat madani, khilafah, islam, demokrasi 


\section{A. Pendahuluan}

Dengan ambrıknya sistem khilafah ${ }^{1}$, negara-bangsa menjadi bagian dari khazanah pemikiran politik Islam, sebagai bagian dari konsekwensi logis masuknya konsep politik Barat ke dalam dunia Islam. Khazanah pemikiran politik Islam klasik tidak mengenal kecuali konsep negara berdasarkan agama, yaitu negara-Islam, negara dzimmi dan negara-harb ${ }^{2}$. Warga negara dalam negara yang dibentuk berdasarkan agama ditentukan oleh faktor agama yang dipeluknya.

Ketika disadari bahwa lembaga khilafah gagal dipertahankan umat Islam, pemikiran politik Islam berusaha mengembangkan wacana negara yang tidak didasarkan pada agama. ${ }^{3}$ Pada masa modern, antara lain seluruh wilayah yang semula berada dalam kekuasaan kekhalifahan Turki Usmani terpecah ke dalam bebcrapa negara baru, menandai keberhasilan anggota komunitas yang tinggal di wilayah-wilayah tersebut dalam meraih kemerdekaan wilayahnya. Pembentukan negara-negara baru itu tidak didasarkan pada agama mayoritas penduduk yang tinggal di dalamnya, akan tetapi didasarkan aspek kebangsaan ${ }^{4}$. Dengan perkembangan itu, umat Islam sebagai bagian dari penduduk wilayah setempat menghadapi konsep politik negara-bangsa. ${ }^{5}$ Untuk bangsa Indonesia, negara yang telah dibentuk oleh mayoritas umat Islam itu ternyata justru mendominasi warga negara yang membentuknya ${ }^{6}$.

\footnotetext{
'Penghapusan lembaga khilafah terjadi pada 3 Maret 1924. Lihat Jere L. Bacharach, A Middle East Studies Handbook, (Cambridge: Cambridge University Press, 1989), hal. 67.

"Ibrahim Hoesn, "Fiqh Siyasah Dalam Tradisi Pemikiran Islam Klasik", dalam Jumal Ulumul Qur'an, Nomor 2, Vol IV/1993, hal. 58-66.

${ }^{3}$ Salah seorang pemikir Islam yang mengadopsi pemikiran negara-bangsa, yakni dengan menolak lembaga khilafah sebagai tuntutan agama segera setelah penghapusan lembaga khilafah adalah Ali Abdul Raziq. Lihat Ali Abdul Raziq, al-Islam wa Usbul al-Hukmi, Babtsun fi al-Kbilafati wa al-Hueumati fi al-Islami, (Mesir: Mastbaah Misr Syarikah Musahirah Misriyah, 1925), terutama hal. 81-83.

${ }^{4}$ Badri Yatim, Sejarab Peradaban Islam, Dirasah Islamiyah II, Jakarta: Raja Grafindo Persada, 1995), hal. 166

${ }^{5}$ Azyumardi Azra, "Islam dan Negara: Eksperimen Dalam Masa Modern, Tinjauan SosioHistoris", dalam Jumal Ulumul Qur'an, Nomor 2, Vol IV/1993, hal. 10-16.

${ }^{6}$ Muhammad AS Hikam, Demokrasi dan Civil Society, (Jakarta: Pustaka LP3ES, 1996), hal. 140.
} 
Pertumbuhan negara yang menghegemoni warga negaranya merupakan sebuah fenomena cukup menarik di Indonesia. Dominasi demikian berdampak pada posisi warga negara yang semakin melemah di hadapan negara. Dalam konteks ini, proses pembelajaran di perguruan tinggi Islam yang mengusung pendidikan kewargaan (Civic Education) untuk pemberdayaan warga-negara menemukan momentumnya yang tepat. Sejauhmanakah wacana Civic Education itu mengambil peran dan fungsi dalam percepatan proses revitalisasi kewarganegaraan melalui penguatan masyarakat madani, merupakan pertanyaan yang cukup menarik untuk didiskusikan. Untuk itu, tulisan ini mengkaji persoalan itu, diawali dengan pengkajian tentang konsep evolusi hak-hak dasar warga negara dan pemaknaannya, persoalaan kewarganegaraan di Indonesia, evolusi pemaknaan masyarakat madani. Tulisan ini akan diakhiri dengan telaah tentang peran dan fungsi wacana Civic Education dalam proses penguatan masyarakat madani di Indonesia.

\section{B. Wacana Warga Negara}

Warga negara adalah warga dari suatu negara-bangsa, bukan negara agama. Sesuai dengan watak asalnya, kewarganegaraan merupakan persoalan yang bersifat netral agama, identitas agama berusaha dipendam dalam-dalam. Keanggotaan suatu komunitas merujuk pada konsep warga negara yang didasarkan pada faktor-faktor etnisitas, bahasa, kewilayahan dan faktor-faktor non-religi lainnya. Kewarganegaraan adalah turunan dari konsep politik negarabangsa yang bersumber dari tradisi Barat yang netral agama.

Dalam tradisi Barat ${ }^{7}$, kajian filosofis terhadap warga negara dimulai pada masa Yunani, ketika ada polis atau negara kota. Anggota-anggota polis adalah orang-orang yang berdaulat dan dijamin hak-haknya. Kedaulatan yang mereka miliki berhubungan dengan proses pengambilan keputusan bersama seluruh anggota polis tanpa terkecuali untuk mengatur kehidupan mereka sendiri. Partisipasi seluruh polis itu merupakan tipe ideal dan pernah menjadi basis

\footnotetext{
'uhammad AS Hikam, Politik Kewnganegaraan, Landasan Redemukratisasi di Indonesia, Oakarta: Erlangga, 1999), hal. 161-164.
} 
pengembangan wacana warga negara modern melalui proses revolusi, seperti yang terjadi di Perancis.

Revolusi Perancis yang terjadi pada abad XVIII menandai pemulaan perjuangan warga Negara dalam merebut kembali hak-haknya dari raja. Revolusi itu memperjuangkan persamaan, persaudaraan dan kebebasan warga Negara yang menginspirasi munculnya wacana ideal warga negara modern. Berbarengan dengan itu, muncul pula konstruksi-konstruksi teoritis yang dikemukakan oleh John Locke, Thomas Hobbes dan Montesqueu yang melegitimasi perlu adanya pengakuan hak-hak dasar manusia.

Menurut Marshal, seperti dikutip AS Hikam ${ }^{8}$, hak-hak dasar dari warga negara berevolusi sesuai dengan kehendak zamannya. Evolusi hak-hak dasar warga ncgara dapat dibagi ke dalam tiga tahapan. Tahap pertama, evolusi yang terjadi pada abad ke 17, saat mana pengakuan hak-hak sipil warga Negara dipcriuangkan. Tahap betikutnya, yang menyusuli keberhasilan memperjuangkan hak-hak sipil warga Negara, perjuangan bergerak untuk memperoleh hak-hak politik. Perjuangan itu antara lain ditandai dengan keberhasilan gerakan kaum buruh di Inggris yang mempunyai hak suara dalam pemilihan umum pada abad ke-19. Dan pada tahap ketiga dari evolusi hak-hak warga Negara, sebagai kelengkapan dari keberhasilan warga Negara dalam memperoleh hak sipil dan hak politik, warga Negara pada abad ke-20, berjuang untuk memperoleh hak-sosial dan hak ekonomi.

Periuangan untuk memperoleh hak sosial dan hak ekonomi menginspirasi munculnya gagasan welfare-state. Kaum buruh bukan hanya diperjuangkan untuk memperoleh hak politik, akan tetapi juga memperoleh hak ekonominya, agar dapat hidup secara wajar, makmur dan bebas dari eksploitasi para borjuasi atau kaum kapitalis. Perkembangan berikutnya, Marshall meramalkan munculnya evolusi warga Negara yang menuntut hak-kultural. Tuntutan itu nampaknya sudah mulai muncul di mana indigenous right, hakhak kultural dari orang-orang lokal semakin diangkat ke permukaan, termasuk

"Mohammad AS Hikam, "Gerakan Politik Warga Negara", dalam Mohammad Nastain dan A. Yok Zakaria Ervani (ed.), Figh Kewarganegaraan, Intervensi Agama-Negara Terbadap Masyarakat Sipil, (Jakarta: PB-PMII, 2000), hal. 4-5 
hak-hak kultural orang gay, aborsi dan hak untuk mengamalkan kepercayaannya.

Dalam konteks Indonesia, perjuangan warga Negara untuk memperoleh hak-haknya cukup menarik dicermati. Persoalan warga negara di Indonesia dalam sejarahnya tidak mengalami evolusi seperti tersebut di atas. Hak warga negara di Indonesia diperjuangkan bukan hanya berdasarkan kelas sosial (social class), tetapi diperjuangkan dalam rangka menghadapi kolonialisme. Hak-hak sipil sebagai hasil dari evolusi pada abad ke-18 di Eropa, dalam konteks Indonesia justru baru muncul pada abad ke-20, sehingga kita harus berjuang lebih jauh melalui berbagai evolusi konsep warga negara. Sayangnya, persoalan warga negara di Indonesia dipahami tidak dalam konteks perjuangan pemenuhan hak-hak dasarnya, akan tetapi hanya dimengerti pada batasan yang legalistik. Warga negara ditafsirkan sebagai orang yang mempunyai kedudukan dan diakui oleh negara sebagai warga dari negara, udak dikaitkan dengan hakhak dasar, seperti hak politik, hak sosial dan hak ekonomi.

Dalam konteks tersebut, persoalan warga negara atau kewarganegaraan lebih ditekankan atau bahkan hanya berkisar pada urusan KTP (Kartu Tanda Penduduk), paspor, kawin dan sejenisnya. Hal ini tentu saja sebuah ironi, karena sesungguhnya masalah kewarganegaraan itu adalah persoalan yang sangat mendasar di dalam politik atau demokrasi modern. Ia akan berimplikasi pada susunan masyarakat atau susunan politik dan sistem politik yang berdasarkan hak-hak dasar. Demokrasi tanpa berpijak pada landasan hak-hak dasar kewarganegaraan, terurtama hak politik dasar seperti hak berbicara, berkumpul dan berorganisasi, tidak ada artinya.

Jika kita rujuk perjalanan sejarah kewarganegaraan kita, maka tercatat bahwa dalam sidang-sidang BPUPKI, PPKI dan Konstituante pernah terjadi perdebatan panjang mengenai hak-hak dasar ini. Perdebatan panjang mengenai hak-hak dasar ini, dalam sidang BPUPKI dimainkan oleh Soepomo dan Soekarno di satu pihak yang berdebat melawan Muhammad Yamin dan Muhammad Hatta di pihak lain.?

9Saafroedin Bahar (dkk), Risalah Sidang BPUPKI-PPKI, Jakarta: Sekretariat Negara RI, 1995), xix, bandingkan misalnya dengan hal $37 \mathrm{dst}$. 
Bagi Soepomo dan Soekarno, hak-hak dasar warga negara tidak perlu dicantumkan dalam UUD secara eksplisit. Alasan mereka, dengan adanya negara integtalistik maka tidak relevan berbicara mengenai hak-hak dasar yang hanya dikenal di negara-negara yang menganut paham individualistis. Padahal, demikian menurut mereka, di dalam paham integralis, negara mengatasi golongan dan individu. Oleh karena itu, negara tidak lagi harus memikirkan mengenai hak-hak warga, karena secara otomatis tercakup di dalam negara itu.

Gagasan semacam itu ditolak oleh Muhammad Yamin dan Muhammad Hatta. Alasannya, jika hak-hak warga negara tidak tercantumkan secara eksplisit maka negara berpeluang untuk melakukan kesewenang-wenangan. Muhammad Hatta menambahkan argumentasinya bahwa negara yang (akan) didirikan oleh bangsa Indonesia adalah negara yang (akan) memberikan posisi yang jelas mengenai hak-hak dasar kewarganegaraannya. Oleh karena itu, perlu dimasukkan pasal-pasal mengenai hak-hak dasar kewarganegaraan secara eksplisit, betatapun kurang lengkap dan perlu dikembangkan lagi.

Dalam perkembangannya, gagasan Soepomo dan Soekarno itu mendapat sambutan yang luas. ${ }^{10}$ Dekrit presiden pada 5 Juli 1959 menandai babak baru yang semakin melemahkan posisi warga Negara dalam memperjuangkan hak-haknya. Babak baru itu menandai pemberdayaan yang lebih terfokus pada negara. Apa yang dianggap benar oleh negara itulah yang menjadi fokus dari pengembangan sistem politik. Bahkan semakin direduksi bahwa yang disebut Negara itu bukan institusi akan tetapi person atau tokoh dari negara, yaitu presiden.

Pelemahan terhadap posisi warga negara itu rupanya dilanjutkan pada era Orde Baru. "Orde Baru mempunyai suatu kerangka yang lebih kokoh lagi dalam memperkuat posisi negara. Pemerintah Orde Baru memiliki legitimasi ekonomi dengan wujud basis material yang cukup kuat setidak-tidaknya pada masa awalnya. Dimulai dari pengambil-alihan kekuasaan pada tahun 1965, Orde Baru mendapat legitimasi sangat kuat, bukan saja dari Indonesia tetapi juga

\footnotetext{
${ }^{10}$ Adnan Buyung Nasution, Aspirasi Pemerintahan Konstitusional di Indonesia, Studi Sosio-Legal atas Konstztuante 1.956-1959, terj. Sylvia Tiwon, Jakarta: Pustaka Utama Grafiti, 1995), hal.. xxxv dan 182-192.

"Din Syamsuddin, Islam dan Politik, Era Orde Baru, Jakarta: Logos, 2001), hal. 39-40.
} 
komunitas internasional terutama dari modal kapitalis luar negeri. ${ }^{12}$ Terutama kapitalis luar negeri berusaha meletakkan Indonesia dalam orbit kapitalisme global. Dari sinilah Orde Baru mengembangkan prinsi-prinsip negara integralistik yang menyebabkan negara menjadi semakin kuat.

Persoalan pemberdayaan warga negara dalam posisi dan relasinya dengan negara adalah wacana yang jauh panggang dari api pada masa Orde Lama dan lebih-lebih pada masa Orde Baru. Secara nyata negara melakukan hegemoni terhadap warga negara. Wacana kewarganegaraan, demokrasi dan apa saja yang menjadi alat-alat di negara yang modern, dapat saja diperbincangkan pada Orde Baru namun hal itu sama sekali tidak dalam substansinya.

Dari pemaparan di atas, nampak dalam sejarah kewarganegaraan di Indonesia bahwa konsep kewarganegaraan yang berkembang adalah gagasan Soepomo dan Soekarno. Maksudnya, perlindungan terhadap hak-hak dasar warga negara tidak dinyatakan secara eksplisit dalam UUD. Yang menjadi pertanyaan sekarang adalah bagaimana memperbaiki kesejarahan warga negara di Indonesia, misalnya dalam pemberdayaan dan perlindungan atas hak-hak dasarnya? Munculnya beberapa paradigma alternatif dalam kajian politik dan pembangunan dalam khazanah pemikiran di Indonesia dapat dilihat sebagai wacana untuk mencari solusi atas keterpurukan persoalan kewarganegaraan di Indonesia. Salah satu alternatif itu adalah revitalisasi paradigma kewarganegaraan.

Sesungguhnya revitalisasi atas paradigma kewarganegaraan telah memiliki akar historis yang panjang, namun ia agak lama "terlupakan" oleh paradigma mainstream. Revitalisasi atas paradigma kewarganegaraan tersebut mencapai momentum pada akhir dekade delapan puluhan bersamaan dengan kemunculan kembali kajian tentang Civil Sociery (Masyarakat Madani). Pada kenyataannya, kewarganegaraan maupun Masyarakat Madani kemudian berkembang bersama-sama dan menghasilkan berbagai variasi pendekatan teoritis maupun pragmatis. Maka, muncul pertanyaan menarik, adakah benang merah yang menyambung keduanya, yaitu kepedulian serta komitmen terhadap kembalinya masyarakat ataupun warga negara sebagai pusat dan aktor utama

\footnotetext{
${ }^{12}$ Muhammad AS Hikam, Demokrasi dan Civil Society, hal. 135.
} 
baik dalam wacana maupun praksis politik pembangunan. Berikut ini, kajian akan difokuskan pada persoalan masyarakat madani, sejauh mana relevansinya dalam penguatan hak-hak dasar warga negara, sebagai prasyarat agar warga negara mampu untuk melakukan tugasnya dalam kehidupan publik.

\section{Wacana Masyarakat Madani di Indonesia}

Kendati civil society berasal dari tradisi Barat, ia tidak menjadi monopoli Barat. Menariknya, bila dikembangkan di tempat lain maka civil society bisa memiliki atribut dan penampakan yang tidak selalu serupa dengan yang dikembangkan di dunia Barat. Dalam perkembangannya di Indonesia, wacana civil society diterjemahkan ke dalam bahasa Indonesia dengan istilah masyarakat madani. Istilah Masyarakat Madani itu sendiri sebenarnya hanya salah satu dari beberapa istilah lain yang seringkali digunakan orang dalam menerjemahkanan civil society ke dalam bahasa Indonesia. Di samping Masyarakat Madani, padanan kata lainnya yang sering digunakan adalah masyarakat warga atau masyarakat kewargaan, masyarakat sipil, masyarakat beradab atau masyarakat berbudaya. ${ }^{13}$

Untuk pertama kalinya, Masyarakat Madani diperkenalkan di Indonesia oleh Dato Anwar Ibrahim, ketika menjadi Wakil Perdana Mentri Malaysia. Dalam ceramahnya pada acara Temu Ilmiah Festifal Istiqlal, ia memandang sama istilah masyarakat madani dan civil society. Menurut Dawam Rahardjo, Anwar Ibrahim menterjemahkannya dari bahasa Arab, mujtama’ madani yang diperkenalkan oleh Naguib al-Attas. ${ }^{14}$

Pembahasan mengenai istilah masyarakat madani yang disamakan dengan civil society itu cukup menggugah perhatian masyarakat muslim khususnya. Masyarakat Islam telah cukup antusias dalam memberikan perhatian terhadap konsep masyarakat di samping perhatiannya terhadap semakin kuatnya negara (state). Yang cukup menarik dari penterjemahan wacana civil society

13 Adi Suryadi Culla, Masyarakat Madani, Pemikiran, Teori dan Relevansinya dengan Cita-rita Reformasi, (Jakarta : RajaGrafindo Persada, 1999), hal. 3-9

14 M. Dawam Rahardjo, "Masyarakat Madani", Bahan Bacaan Lokakarya Islam dan Pemberdayaan Civil Society di Indonesia, Lokakarya hasil kerja sama WRI Semarang engan PPIM Jakarta, 13-14 Juni 2000, hal. 1-25. 
dengan istilah masyarakat madani ini antara lain adalah kenyataan bahwa wacana masyarakat madani itu tidak menimbulkan kecurigaan dari kalangan agama lain, sehingga istilah itu sekarang diterima secara umum. Di samping itu, patut ditambahkan, bahwa penemuan istilah masyarakat madani itu cukup membantu penerimaan wacana civil society di Indonesia.

Meskipun demikian, apakah masyarakat madani memang identik dengan civil society, ada silang pendapat. Jika dilihat dari asal kelahirannya, agaknya konsep masyarakat madani ini tidak identik dengan civil society. Pertama-tama, civil society dinilai berasal dari sejarah Eropa Barat dan Amerika Utara. Kedua, civil society mengimplikasikan pengertian sekularisme. Ketiga, masyarakat madani itu cakupannya lebih luas dari civil society. ${ }^{15}$

Sebagai konsep yang berasal dari Barat, sebenarnya konsep civil society ini erat kaitannya dengan sekularisme. Dalam pandangan ini, civil society dianggap akan menjadi kuat dari cengkeraman negara. Ia akan menjadi kuat di pangkuan masyarakat sendiri. Demikian juga agama akan menjadi kuat jika dapat keluar dari cengkeraman negara. Karena itu maka agama harus diserahkan kepada masyarakat sendiri. Namun kalangan Islam tidak menyetujui konsep pemisahan agama dan negara. Civil society dapat dipisahkan dari negara. Tetapi nilai-nilai agama harus dapat bermain baik pada tataran masyarakat maupun negara. Konsep masyarakat madani dianggap membebaskan civil society dari sekularisme. Karena itu gagasan dasar civil society dapat diterima dengan istilah masyarakat madani dan sebaliknya, dalam konsep masyarakat madani ini, civil society mendapatkan justifikasi.

Hal lain yang patut diperhatikan adalah mengenai cakupan masyarakat madani. Konsep masyarakat madani juga mencakup political society atau negara. ${ }^{16}$ Selain itu, jika civil society merupakan ruang hidup yang telah

${ }^{15}$ Asep Gunawan dan Dewi Nurjulianti (pen), Gerakan Keagamaan Dalam Pengualan Ciril Society, Analisis Perbandingan Visi dan Misi LSM dan Omas Berbasis Keagamaan, Oakarta: LSAF, 1999), hal. xxii-xxiii.

${ }^{16}$ Istilah political society dan civil society ada yang mempersepsikannya berarti sama namun ada pula yang menganggap beda. Misalnya, konsep John Locke dan Rousseau, tidak membedakan antara political society dengan civil society, kedua istilah itu dianggap sama. Kedua istilah itu menunjuk pada pengertian negara dan sekaligus pemerintahan sipil, hal itu berbeda dari istilah state of nature, sebuah situasi tanpa pemerintahan, sebuah imaginasi kehidupan 
meninggalkan individu dan keluarga, masyarakat madani ingin menghidupkan kembali peranan individu dan keluarga. Dengan demikian, masyarakat madani adalah sebuah masyarakat ideal, di mana civil society, yang agaknya hingga kini masih sulit ditemukan terjemahannya yang tepat itu, adalah merupakan bagian saja dari masyarakat madani. Di sini civil society diartikan sebagai suatu "ruang publik" yang independen dari negara sebagaimana didevinisikan Haberman. Tapi ruang publik bebas itu merupakan bagian yang esensial dari masyarakat madani, bahkan merupakan ciri utamanya.

Meskipun ternyata dapat ditemukan beberapa perbedaan antara kedua istilah itu, namun untuk uraian berikut ini dan untuk kepentingan tulisan ini, istilah masyarakat madani dibiarkan dipertukarkan dengan civil society.

\section{Pemaknaan Masyarakat Madani}

Masyarakat madani (civil society), baik sebagai wacana teoritis maupun praktis dilahitkan dari rahim budaya Barat. Sebagai sebuah wacana, masyarakat madani adalah produk sejarah dan masyarakat Barat modern. Ia muncul bersamaan dengan proses modernisasi, terutama pada saat terjadi transformasi dari masyarakat feodal menuju masyarakat industrial kapitalis. Masyarakat madani sebagai gagasan adalah anak kandung Filsafat Pencerahan, yang meretas jalan bagi munculnya sekularisme sebagai pandangan dunia yang menggantikan agama, dan sistem politik demokrasi sebagai pengganti sistem monarki. Selanjutnya, konsep masyarakat madani itu mengalami pelbagai model pemaknaan, sejalan dengan keragaman dan dinamika pemikiran serta konteks sosio historis tempat pemikiran itu dirumuskan.

masyarakat yang tanpa negara. Demikian juga Heningsen memandang bahwa civil society tidak lain adalah constitutive condition dari political society, maka civil society dan political society pada dasarnya dapat dipertukarkan. Sementara di sisi lain, Hegel, Marx, Gellner, Cohen dan Arato melihat kedua istilah itu yakni political society dan civil society sebagai dua hal yang berlainan, bahkan bertentangan. Kedua istilah tersebut, menurut persepsi terakhir ini, dilihat sebagai representasi dua entitas yang berdiri sendiri atau dua domain politik yang berbeda. Lihat Riswanda Imawan, "Rekruitmen Kepemimpinan Di Daerah: Antara Keinginan dan Kebutuhan Masyarakat", dalam Jumal Ilmu Politike No 17, (Jakarta: Gramedia-AIPI, 1997), 21 dan M Ryaas Rasyid, "Pcrkembangan Pcmikiran tentang Masyarakat Kewargaan (tinjauan Teoritik)", dalam Jurnal Ilmu Politik No 17, hlm 3-9; Adi Suryadi Culla, Masyarakat Madani, Pemikiran, Teori dan Relevansinya dengan Cita-cita Reformasi, Jakarta : RajaGrafindo Persada, 1999), 67-68. 
Evolusi pemaknaan pertama, masyarakat madani (civil society) dipahami sebagai sistem kenegaraan. Artinya, masyarakat madani identik dengan negara. Pemahaman demikian dikembangkan oleh Aristoteles (yang menggunakan istilah koinonia politike), Marcus Tullius Cicero (dengan istilah societas civilis) serta Thomas Hobbes dan John Locke (dengan pemahaman bahwa civil society adalah tahapan lebih lanjut dari evolusi natural sociery. $)^{17}$ Bagi Hobbes, kemunculan masyarakat madani bertujuan untuk meredam konflik dalam masyarakat, sehingga masyarakat tidak jatuh dalam chaos atau anarki. Karenanya, menurutnya, masyarakat madani harus memiliki kekuasaan mutlak agar mampu sepenuhnya mengontrol dan mengawasi secara ketat pola-pola interaksi (perilaku politik) setiap warga. Sementara bagi John Locke, kehadiran masyarakat madani dimaksudkan untuk melindungi kebebasan dan hak milik setiap warga negara. Akibatnya masyarakat madani tidak boleh absolut. Ia harus membatasi perannya pada wilayah yang tidak bisa dikelola masyarakat dan memberi ruang yang manusiawi bagi warga negara untuk memperoleh haknya secara adil dan proporsional.

Pemaknaan kedua, masyarakat madani versi Adam Ferguson. Dengan mengambil konteks sosial politik Skotlandia, Ferguson memberi tekanan terhadap makna masyarakat madani sebagai sebuah "visi etis dalam kehidupan bermasyarakat". Dengan masyarakat madani, ia berharap kembalinya semangat publik untuk menghalangi munculnya despotisme. Sebab, dalam masyarakat madani itulah solidaritas sosial muncul yang diilhami oleh sentimen moral dan sikap saling menyayangi serta saling membangun kepercayaan antar-warga secara alamiyah. Jadi pemaknaan Ferguson terhadap masyarakat madani didasarkan atas kekhawatiran akan lunturnya tanggungjawab sosial masyarakat dan menguatnya individualisme.

Ketiga, versi Thomas Paine. Pemahaman Thomas Paine. mengawali pemaknaan masyarakat madani dalam posisinya yang berhadapan secara diametral dengan negara. Bahkan, masyarakat madani dinilai sebagai antitesis

\footnotetext{
${ }^{17}$ Koinonia politike adalah sebuah komunitas politik tempat warga dapat terlibat langsung dalam pelbagai pertandingan ekonomi politik dan pengambilan keputusan; Societas civilis adalah sebuah komunitas yang mendominasi sejumlah komunitas lain.
} 
negara. Menurut Paine, masyarakat madani adalah ruang di mana warga dapat mengembangkan kepribadian dan memberi peluang bagi pemuasan kepentingannya secara bebas dan tanpa paksaan. Ia mengidealkan terciptanya suatu ruang gerak yang menjadi domain masyarakat, di mana intervensi negara ke dalamnya merupakan sesuatu yang tidak syah. Karena itu, tentu saja masyarakat madani mesti lebih kuat dan mengontrol negara demi kebutuhannya.

Keempat, masyarakat madani dimaknai sebagai "elemen ideologi kelas dominan". Pemikir yang dapat dikelompokkan ke dalam kategori keempat inj antara lain adalah Hegel, Marx dan Gramsci. Pemaknaan seperti dilakukan oleh Paine telah memancing reaksi Hegel untuk mengembangkan masyarakat madani yang subordinatif terhadap negara. Hegel berpendapat, struktur sosial terbagi atas tiga entitas, yaitu keluarga, masyarakat madani dan negara. Baginya, masyarakat madani adalah entitas yang cenderung melumpuhkan dirinya sendiri dan karenanya memerlukan santunan negara lewat kontrol hukum, administrasi dan politik. Ia secara konstan membutuhkan kontrol dan supervisi dari negara. Intervensi negara itu legitimate.

Bagi Hegel ada dua kondisi yang mengabsahkan intervensi negara dalam masyarakat. Pertama, bila terjadi ketidakadilan dan ketidaksederajatan dalam masyarakat. Kedua, jika terjadi sesuatu yang mengancam kepentingan universal masyarakat, sehingga tindakan perlindungan atas kepentingan dimaksud perlu dilakukan.

Marx tampaknya mengikuti asumsi Hegel tentang masyarakat madani. Namun pandangan Marx menjungkirbalikkan visi Hegel tentang negara. Dalam visi Marx, justru negaralah yang suatu ketika akan lenyap. Dengan lenyapnya negara, maka masyarakat madani dengan sendirinya akan lenyap juga karena negara kapitalis mengandaikan adanya masyarakat madani. Sedangkan Antonio Gramsci, meski penganut Marx, ia tidak memahami masyarakat madani dari relasi produksi tetapi lebih pada sisi ideologis. Gramsci menempatkan masyarakat madani pada superstruktur, ${ }^{18}$ berdampingan dengan negara yang ia

\footnotetext{
${ }^{18}$ Saiful Arif (cd.), Pemikiran-Pemikiran Revolusioner, (Yogyakarta: Pustaka Pelajar, 2001), hal. 48-49 dan hal. 90-92.
} 
sebut sebagai political society. Masyarakat madani adalah tempat perebutan posisi hegemonik di luar kekuatan negara. Di dalamnya, aparat hegemoni mengembangkan hegemoni untuk membentuk konsensus dalam masyarakat. Kemungkinan bagi munculnya kontra hegemoni dari luar kekuasaan negara, dicatat pula oleh Gramsci. Namun ia dengan nada optimis menegaskan bahwa drama akhir dari proses itu adalah terserapnya negara dalam masyarakat madani sehingga kemudian terbentuklah apa yang disebut masyarakat teratur.

Evolusi pemaknaan masyarakat madani kelima merupakan reaksi atas model Hegelian. Pemikir dalam pemaknaan kelima ini adalah Alexis de Tocquiville yang memaknai masyarakat madani sebagai entitas penyeimbang kekuatan negara. Paradigma ini melihat masyarakat madani sebagai sesuatu yang tidak apriori subordinatif terhadap negara. Ia bersifat otonom dan memiliki kapasitas politik cukup tinggi sehingga mampu menjadi kekuatan penyeimbang untuk menahan kecenderungan intervensionis negara. Bahkan lebih dari itu, masyarakat madani menjadi sumber legitimasi negara, yang pada saat yang sama mampu melahirkan kekuatan kritis reflektif untuk mengurangi derajat konflik dalam masyarakat sebagai akibat proses formasi sosial modern. Masyarakat madani tidak hanya berorientasi kepada kepentingan sendiri, tetapi juga sensitif terhadap kepentingan publik.

Model pemaknaan terakhir inilah yang kemudian diperkaya oleh Hannah Arendt dan Juergen Habermas dengan konsep "ruang publik yang bebas". Pada ruang publik yang bebaslah, individu dalam posisinya yang setara mampu melakukan transaksi-transaksi wacana dan praksis politik tanpa mengalami distorsi dan kekhawatiran. Ruang publik secara teoritik bisa diartikan sebagai wilayah di mana masyarakat sebagai warga negara memiliki akses penuh terhadap setiap kegiatan publik. Warga negara berhak melakukan kegiatan secara merdeka dalam menyampaikan pendapat, berserikat, berkumpul serta mempublikasikan penerbitan yang berkenaan dengan kepentingan umum. Institusionalisasi ruang publik itu menurut Habermas antara lain berupa lembaga-lembaga voluntir, media massa, sekolah, partai politik hingga organisasi yang awalnya dibentuk negara, namun berfungsi sebagai pelayan masyarakat. 
Dari pemaparan di atas, nampak bahwa masyarakat madani menemukan titik singgung yang sama dengan paradigma kewarganegaraan. Baik masyarakat madani maupun paradigma kewarganegaraan keduanya sama-sama menekankan terpenuhinya jaminan-jaminan terhadap hak-hak dasar sebagai prasyarat agar warga negara mampu melakukan tugasnya dalam kehidupan publik. Tanpa ada masyarakat madani yang menjadi landasan kehidupan bermasyarakat, maka akan kesulitan berbicara tentang politik kewarganegaraan. Esensi masyarakat madani adalah ruang, tempat warga negara berinteraksi secara bebas sebagai anggota yang equal, baik dalam transaksi ekonomi, politik, non-partai atau non-agama secara kultural. Jadi, tidak ada politik kewarganegaraan yang tumbuh tanpa adanya masyarakat madani yang mandiri dan kuat. Sebaliknya, tidak mungkin masyarakat madani akan mendorong proses demokratisasi tanpa ada politik kewarganegaraan.

Dengan demikian dapat digarisbawahi tentang hubungan erat antara masyarakat madani dan kewarganegaraan. Masyarakat madani adalah suatu wilayah di luar negara tetapi mempunyai elemen politik di dalamnya yang diwujudkan dalam kewarganegaraan. Maka, penguatan masyarakat madani dapat dilakukan dengan gerakan kewarganegaraan. Salah satu langkah untuk itu adalah membangun visi, misalnya dengan memberi kesadaran kepada masyarakat bahwa warga negara adalah pemilik negara. Pemberian kesadaran politik dapat dilakukan dengan melakukan gerakan dakwah kewargaan, yang terdiri dari proses sosialisasi, internalisasi dan aktualisasi nilai-nilai Islam yang menjunjung tinggi hak dan kewajiban warga Negara.

\section{E. Gerakan Dakwah Kewargaan}

Sebagai wacana, masyarakat madani telah semarak diperbincangkan di Indonesia. Namun pada tingkat aktualisasinya, perlu keikutsertaan seluruh lapisan masyarakat untuk berperan aktif di dalamnya. Peran masyarakat itu dapat diharapkan ketika mereka secara sadar mengalami proses berdemokrasi. Hal itu perlu ditekankan karena bagi masyarakat Indonesia pada umumnya, mengalami demokrasi (experiencing democracy) merupakan sesuatu yang baru. Oleh karena itu, mengalami demokrasi tidak bisa diperlakukan secara taken for granted, 
membiarkannya berkembang apa adanya secara trial and error. Sebaliknya, pengalaman berdemokrasi bahkan tidak hanya diperjuangkan, tetapi lebih dari itu harus disemaikan, ditanamkan, dipup ık dan dibesarkan melalui upaya-upaya terencana, teratur, terarah pada seluruh lapisan masyarakat.

Di antara cara yang cukup strategis untuk mengalami demokrasi adalah melalui democracy education (pendidikan demokrasi). Secara esensial, pendidikan demokrasi menyangkut sosialisasi, diseminasi dan akrualisasi konsep, sistem, nilai, budaya dan praktek demokrasi melalui pendidikan. Pendidikan demokrasi ini berkaitan secara signifikan dengan penumbuhan civic culture untuk keberhasilan pengembangan dan pemeliharaan pemerintahan negara yang demokratis di satu pihak dan penguatan masyarakat madani di pihak lain. Pertumbuhan dan pengembangan civic culture tidak boleh dibiarkan berjalan secara liar. Nilai-nilai Islam yang mengarahkan perkembangan budaya kewargaan, tetap harus menjadi acuan sehingga masyarakat madani yang berkembang tetap berada dalam koridor nilai-nilai keagamaan.

Memberi pengalaman untuk mengalami demokrasi bagi masyarakat luas dapat dilakukan melalui gerakan dakwah kewargaan. Gerakan dakwah kewargaan untuk masyarakat luas itu pada hakikatnya adalah pengembangan cita-cita, nilai, norma, pengetahuan dan ketrampilan demokrasi yang secara psikologis dan sosial dapat memberi kemudahan kepada warga negara dan masyarakat untuk menunjukkan penghargaan dan tanggung jawabnya sebagai aktor sosial dan pemimpin yang cerdas dan bertanggungjawab dalam masyarakat, sesuai dengan nilai-nilai yang dijunjung tinggi oleh Islam. Dengan sasaran tersebut, dakwah kewargaan merupakan wahana berdemokrasi untuk warga negara yang sengaja dirancang, dilaksanakan, dievaluasi dan secara dinamis diperbaharui atas dasar kebutuhan dari masyarakat, dengan usaha sadar oleh masyarakat dan untuk mencapai tujuan masyarakat madani.

Dengan mengadopsi dari pendidikan formal, dakwah kewargaan mengembangkan konsep yang lebih jelas lagi dalam proses sosialisasi, internalisasi dan aktualisasi ${ }^{19}$ nilai-nilai demokrasi yang tidak bertentangan

19 Bandingkan dengan Muhammad Sulthon, Fungsi Dakusab dalam Penyebarluasan Ajaran Shadoqat pada Masa Nabi Mubammad, (Semarang: Walisongo Press 2011), hal. 27-56. 
dengan ajaran Islam guna memberi pengalaman berdemokrasi yang beradab kepada masyarakat luas. Sebagai wahana dan esensi pendidikan demokrasi di masyarakat, dakwah kewargaan tentu berhubungan secara signifikan dengan penguatan masyarakat madani. ${ }^{2 \mathrm{~J}}$ Dakwah kewargaan bertujuan mengembangkan kecetdasan warga negara dalam dimensi spiritual islami, rasional-ilmiyah, emosional dan sosial; tanggungjawab warga negara dan partisipasi warga negara guna menopang tumbuh dan berkembangnya individu warga negara yang cerdas, baik dan beradab dalam rangka mewujudkan masyarakat madani.

Untuk mencapai tujuan itu, pesan dakwah kewargaan dipilih secara psikologis dan ilmiah dengan cermat dan diorganisasikan secara terpadu dalam kerangka cita-cita, konsep, nilai, norma dan praksis demokrasi. Pemilihan dan pengorganisasian pesan dakwah itu, secara psikologis adalah yang relevan dengan perkembangan individu; secara sosial kultural adalah adaptif terhadap berbagai lingkungan social budaya dan secara ilmiah dapat dipcrtanggungjawabkan. Untuk memfasilitasi gerakan dakwah kewargaan yang efektif, pesan dakwah dikembangkan dalam suatu kemasan metode dakwah mujadalah, misalnya dikemas dalam coraknya yang bersifat interaktif dan dialogis yang hal itu digali langsung dari masyarakat sebagai hands-on experience.

Untuk proses internalisasi nilai, interaksi da'I dan mad'u dalam situasi dakwah terbatas dipcrlakukan semacam "ruang publik yang bebas" atau "laboratorium demokrasi", di mana semangat kewarganegaraan yang memancar dari cita-cita dan nilai tersebut diterapkan secara interaktif. Dalam waktu yang bersamaan, komunitas di luat situasi dakwah terbatas tersebut, baik yang bersifat lokal, nasional, regional dan global diperlakukan sebagai global classroom. Dengan demikian secara sosial dan pedagogik, proses internalisasi nilai dalam dakwah kewargaan memadukan secara interaktif pengalaman berinteraksi antara dai dan mad'u dalam lokalitas terbatas dengan kegiatan yang menyentuh langsung kebutuhan masyarakat luas. Dan dengan proses interaksi

\footnotetext{
${ }^{20}$ Udin S Winataputra, “Apa dan Bagaimana Pendidikan Kewarganegaraan: Menuju Suatu Paradigma Baru", Makalah Workshop For Lecturers Dosen LAIN dan STAIN se-Indonesia, Bogor, 6-18 Agustus 2001, hal. 1-5.
} 
dakwah semacam itu, dakwah kewargaan semakin bermakna bagi penguatan masyarakat madani.

Model internalisasi nilai tersebut sering dikenal pula dengan model yang bersifat demokratis. ${ }^{21}$ Model internalisasi nilai secara demokratis dengan substansi pesan dakwah yang berorientasi pada pengalaman berdemokrasi itu tentu memberi peluang seluas-luasnya kepada mad'u untuk mengaktualisasikan diri dalam mengalami sendiri pengalaman berdemokrasi. Dari aktualisasi itu, maka semua aspek yang ingin dikembangkan dapat digerakkan, dapat dikontrol dan dapat dibimbing. Peran da'I dalam proses dakwah lebih dikonsentrasikan perhatiannya kepada perilaku ma'du dalam menggerakkan, mengontrol dan mengarahkan kegiatan menginternalisasikan nilai-nilai, bukan sekedar pada aspek kognitifnya (pengetahuannya). Oleh karena itu, dalam menanamkan nilainilai, dakwah kewargaan tidak berarti dai menjadi pasif akan tetapi perhatiannya lebih terarah pada pekerjaan memotivasi, monitoring, memberi bantuan, memberi bimbingan dan evaluasi.

Dakwah Kewargaan dirancang untuk menumbuhkan mad'u supaya menjadi warga negara yang sadar akan hak dan kewajibannya, memiliki kecakapan intelektual dan kecakapan partisipatoris. Dakwah kewargaan membangun visi yang jelas kepada mad'u, yaitu memberikan kesadaran bahwa masyarakat adalah warga negara, bukan abdi negara atau kawula negara. Merekia dibekali pengetahuan tentang hak-hak dasar warga negara sekaligus pengalaman berdemokrasi misalnya dalam memperiuangkan, mempertahankan dan menjamin hak-hak dasar itu. Pengalaman berdemokrasi itu tercermin pada kecerdasan partisipatoris yang berusaha dialami mad'u dalam proses internalisasi nilai. Mad'u dituntut untuk memiliki keahlian berinteraksi, memantau isu publik dan mempengaruhi kebijakan public. Dengan demkian, jelas bahwa dakwah kewargaan berusaha membentuk warga negara yang siap mengembangkan dan memperkuat keberadaan masyarakat madani.

\footnotetext{
${ }^{21}$ Widodo Usman (dkk), Membongkear "Mitos" Masyarakat Madarn, Yogyakarta: Pustaka Pelajar, 2000), hal.. 304-305.
} 


\section{F. Penutup}

Dari uraian di atas dapat disimpulkan sebagai berikut. Elaborasi tentang rancang bangun dakwah kewargaan berhubungan dengan penguatan masyarakat madani. Gerakan dakwah kewargaan di Indonesia didorong oleh kenyataan bahwa proses demokrasi di Indonesia perlu dipacu lebih keras lagi. Peran negara dalam proses demokratisasi perlu ditingkatkan. Dakwah kewargaan melihat bahwa demokrasi tidak boleh dan tidak akan berhenti. Namun proses itu tidak boleh berjalan tanpa arah. Negara yang bisa berkembang menjadi super body perlu diimbangi dengan kekuatan di luar negara yang bisa dibangun. Dalam konteks inilah dakwah kewargaan mengambil peran sebagai revitalisasi paradigma kewarganegaraan dengan memberi pengalaman berdemokrasi kepada mad'u.

Dari penekanan itu dapat digarisbawahi bahwa, model masyarakat madani yang diacu dakwah kewargaan adalah versi Tocquiville. Negara Indonesia yang telah menghegemoni warga negara Indonesia beberapa waktu yang lalu perlu diimbangi dengan penguatan masyarakat madani. Untuk itu, perlu dilakukan gerakan kewarganegaraan dengan mengambil bentuk dakwah kewargaan. Gerakan dakwah kewargaan dirancang bukan sekedar membentuk visi di lingkungan masyarakat, akan tetapi diharapkan out put dakwah kewargaan dapat mengambil peran aktif dalam penguatan masyarakat madani. Dengan demikian, maka di luar negara, ada kekuatan signifikan yang dapat mengimbangi negara dalam mengawal, mengarahkan dan menegakkan demokrasi.

Dengan rancang bangun dakwah kewargaan seperti terurai di atas, maka dakwah kewargaan memiliki relevansi yang tinggi guna ikut berperan aktif dalam proses pengembangan masyarakat. Ranah pengabdian pada masyarakat, memiliki arti penting bagi pembentukan visi warga negara kepada masyarakat luas, sehingga institusionalisasi ruang-ruang publik menjadi dapat langsung dirasakan oleh masyarakat. 


\section{DAFTAR PUSTAKA}

Ali Abdul Raziq, al-Islam wa Usbul al-Hukmi, Babtsun fi al-Kbilafati wa al-Hukumati fi al-Islami, (Mesir: Mastbaah Misr Syarikah Musahirah Misriyah, 1925)

Adnan Buyung Nasution, Aspirasi Pemerintahan Konstitusional di Indonesia, Studi Sosio-Legal atas Konstituante 1956-1959, terj. Sylvia Tiwon, Jakarta: Pustaka Utama Grafiti, 1995)

Adi Suryadi Culla, Masyarakat Madani, Pemikiran, Teori dan Relevansinya dengan Cita-cita Reformasi, (Jakarta : RajaGrafindo Persada, 1999)

Asep Gunawan dan Dewi Nurjulianti (pen), Gerakan Keagamaan Dalam Penguatan Civil Societym Analisis Perbandingan Visi dan Misi LSM dan Ormas Berbasis Keagamaan, (Jakarta: LSAF, 1999)

Azyumardi Azra, "Islam dan Negara: Eksperimen Dalam Masa Modern, Tinjauan Sosio-Historis", dalam Jumal Ulumul Qur'an, Nomor 2, Vol IV $/ 1993$

Azyumardi Azra, "Pendidikan Kewargaan Untuk Demokrasi di Indonesia", makalah Work Shop For Lecturers Dosen LAIN dan STAIN se-Indonesia, Bogor, 6-18 Agustus 2001

Badri Yatim, Sejarab Peradaban Islam, Dirasab Islamiyah II, Jakarta: Raja Grafindo Persada, 1995)

Din Syamsuddin, Islam dan Politik Era Orde Baru, Oakarta: Logos, 2001)

Ibrahim Hoesn, "Fiqh Siyasah Dalam Tradisi Pemikiran Islam Klasik", dalam Jumal Ulumul Qur'an, Nomor 2, Vol IV/1993,

Jere L. Bacharach, A Middle East Studies Handbook, (Cambridge: Cambridge University Press, 1989)

M Ryaas Rasyid, "Perkembangan Pemikiran tentang Masyarakat Kewargaan (tinjauan Teoritik)", dalam Jumal Ilmu Politik No 17, Jakarta: GramediaAIPI, 1997),

M. Dawam Rahardjo, "Masyarakat Madani", Baban Bacaan Lokakarya Islam dan Pemberdayaan Civil Society di Indonesia, di Semarang, 13-14 Juni 2000, WRI Semarang-PPIM Jakarta, 
Muhammad Sulthon, Fungsi Dakwab dalam Penyebarluasan Ajaran Shadaqat pada Masa Nabi Mubammad, (Semarang: Walisongo Press 2011),

Muhammad AS Hikam, Demokrasi dan Civil Society, Jakarta: Pustaka LP3ES, 1996),

Muhammad AS Hikam, Politik Kewrganegaraan, Landasan Redemokratisasi di Indonesia, (Jakarta: Erlangga, 1999),

Mohammad AS Hikam, "Gerakan Politik Warga Negara", dalam Mohammad Nastain dan A. Yok Zakaria Ervani (ed.), Figh Kewarganegaraan, Intervensi Agama-Negara Terbadap Masyarakat Sipil, (Jakarta: PB-PMII, 2000)

Riswanda Imawan, "Rekruitmen Kepemimpinan Di Daerah: Antara Keinginan dan Kebutuhan Masyarakat", daiam Jurnal Ilmu Politike No 17,

Robert W Hefner, Islam dan Demokratisasi di Indonesia, Civil Islam, terj. Ahmad Baso, (Jakarta: ISAI, 2001)

Saafroedin Bahar (dkk), Risalah Sidang BPUPKI-PPKI, Jakarta: Sekretariat Negara RI, 1995)

Saiful Arif (ed.), Pemikiran-Pemikiran Revolusioner, (Yogyakarta: Pustaka Pelajar, 2001)

Tim Penulis, Pendidikan Kewargaan (Civic Education), Demokrasi, HAM dan Maryarakat Madani, (Jakarta: IAIN Jakarta Press, 2000)

Udin S Winataputra, "Apa dan Bagaimana Pendidikan Kewarganegaraan:

Menuju Suatu Paradigma Baru", Makalah Workshop For Lecturers Dosen LAIN dan STAIN se-Indonesia, Bogor, 6-18 Agustus 2001

Widodo Usman (dkk), Membongkar "Mitos" Masyarakat Madani, (Yogyakarta: Pustaka Pelajar, 2000)

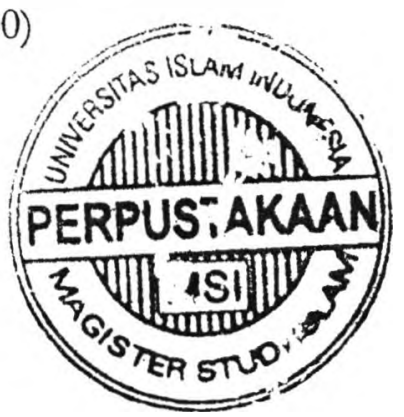

